\title{
KISAH HIDUP KORBAN BULLYING DALAM DOKUMENTER PERFORMATIF “REPOST”
}

\author{
Vera Isnaini \\ Arif Sulistiyono \\ Gregorius Arya Diphayana \\ Jurusan Film \& Televisi, Fakultas Seni Media Rekam, Institut Seni Indonesia Yogyakarta \\ J1. Parangtritis km. 6.5 Yogyakarta Telp. (0274) 381047
}

\begin{abstract}
Negative side of bullying is the main theme of "REPOST" documentary. The making of "REPOST" aimed to deliver a story and perception of bullying by Vera (Nia's sister) through the bullying case of Vera's sister, $\mathrm{Nia}$. This film appears under the performative mode. According to Bill Nichols, performative mode contains three aspect, subjective, related to memory and experience, and expressive.

The performative mode of this film formed by putting Vera as the narrator owning a personal point of view to describe the phenomena of bullying through her sister case. Information and story are delivered by reconstruction, symbol, and expressively using cinematography elements.

Performative documentary film brings personal and emotional intensities from the subject to deliver the case inside the film. The performative mode in "REP OST" documentary can deliver the emotion of Vera and her contradiction of her sister bullying case.
\end{abstract}

Keyword: documentary, performative, bullying, reconstruction

\begin{abstract}
ABSTRAK
Film dokumenter performatif "REPOST" mengangkat tema besar dampak negatif bullying. Penciptaan karya film dokumenter "REPOST" digunakan untuk menyampaikan cerita dan persepsi Vera (adik) terhadap kisah hidup Nia, kakak dari Vera, sebagai korban bullying. Film dokumenter ini dikemas dengan bentuk performatif. Bentuk/mode performatif menurut Bill Nichols memiliki ciri-ciri subjektif, bersifat memory and experience, dan ekspresif.

Bentuk performatif pada film ini dibangun dengan menempatkan Vera (adik) sebagai narator yang memiliki sudut pandang personal dalam memandang fenomena bullying melalui kasus kakaknya. Penyampaian informasi dan cerita dilakukan melalui rekonstruksi simbol dan secara ekspresif menggunakan unsur-unsur sinematik dalam mendukung penyampaian informasi.

Dokumenter performatif berangkat dengan tujuan memberikan intensitas personal dan emosional seorang subjek dalam menyampaikan kasus di dalamnya. Penggunaan bentuk performatif pada film dokumenter "REPOST" dapat menyampaikan emosi dari Vera serta menyampaikan ketidakberpihakan dia terhadap kasus bullying kakaknya.
\end{abstract}

Kata kunci: dokumenter, performatif, bullying, rekonstruksi

\section{Pendahuluan}

Dalam halaman berita $\mathrm{CNN}$, hingga pertengahan tahun 2017, kementrian sosial Indonesia menerima ratusan laporan terkait intimidasi alias bullying melalui pengaduan langsung dan tidak langsung. Hal tersebut memberikan sebuah peringatan bahwa kasus bully saat ini masih terus berlangsung. Padahal, korban dari kasus bully bisa mendapatkan efek jangka pendek dan panjang, misalnya sulit untuk beradaptasi dan memiliki teman dekat. Selain itu, korban bully akan beradaptasi dengan 
sangat buruk sehingga mendapatkan masalah emosional dan masalah kriminal besar. Efek jangka panjang bisa berupa tingkat depresi tinggi dan keinginan untuk bunuh diri.

Kasus bullying bisa terjadi di mana saja termasuk sekolah baik itu bullying verbal, non verbal, maupun fisik. Bullying verbal adalah salah satu jenis bullying berupa ejekan atau kata-kata yang dapat menyakiti hati orang. Ejekan tersebut dapat berupa sebutan khusus (bersifat negatif) untuk target, ejekan mengenai latar belakang target, termasuk ejekan mengenai kondisi fisik sehingga korban/target merasa risih dan tersinggung sering diistilahkan sebagai body shaming.

Indonesia adalah salah satu negara yang fokus terhadap isu body shaming. Para pelaku body shaming dapat diberikan hukuman sesuai dengan undang-undang yang berlaku. Bullying berupa body shaming dialami seorang wanita bernama Nia, kakak dari Vera. Kasus ini terjadi di Instagram. Jika dilihat latar belakang sosial Nia, ini bukan kali pertama Nia mendapatkan bullying dari teman-temannya.

Vera (adik) dan Nia (kakak) adalah dua orang saudara dengan perbedaan umur tiga tahun. Mereka sudah bersama sedari kecil, mulai dari berbagi kamar bersama, sekolah di tempat yang sama, bermain bersama, dan banyak hal lain yang dilakukan bersama. Hal tersebut membuat mereka bisa peka terhadap perasaan satu sama lain.

Kehidupan sosial Nia tidak berjalan dengan baik. Dia banyak mendapatkan bullying dari teman-teman di sekitarnya. Mulai dari sekolah dasar hingga menginjak masa pasca perkuliahan. Kasus tersebut bukan sebuah kasus biasa. Bahkan Nia pernah mengalami depresi pada bangku perkuliahan. Sebagai seorang saudara, adik merasa sangat kesal dan emosi ketika mendengar laporan dari Nia mengenai tingkah laku temannya.

Dokumenter performatif menawarkan sebuah subjektivitas. Adanya sebuah privasi dalam konten dokumenter, dikombinasikan dengan teknik berekspresi melalui gambar dan suara untuk dapat menunjang penyampaian sebuah affective, atau segala sesuatu berkenaan dengan perasaan, untuk menghadirkan keintiman antara subjek dengan penonton.

Karya ini dibuat untuk menceritakan bagaimana kisah dan perasaan keluarga terhadap kasus bullying yang diterima Nia dengan misi utama untuk memberi dukungan moral kepada Nia. Selain itu, film ini diharapkan bisa menjadi referensi baru bagi penelitian dan penciptaan karya, khususnya film dokumenter.

\section{Pembahasan}

Film dokumenter "REPOST" merupakan salah satu istilah di Instagram dengan arti mengunggah ulang unggahan pengguna akun Instagram lain. Kata repost mengaju pada cerita dalam film ini yaitu pada saat akun Pontianak Media 
mengunggah ulang video Nia sebagai materi akun Instagramnya.

Sebuah film dokumenter dengan bentuk performatif memiliki ciri-ciri bersifat subjektif, ekspresif, bersifat ingatan, dan pengalaman (Nichols, 2010:203-206). Seluruh isi dari film dokumenter diangkat dari ingatan dan pengalaman Vera dan Nia. Subjektivitas dalam film dokumenter performatif dapat menjelaskan secara langsung keterlibatan pembuat film di dalam film dan posisi keberpihakan pembuat film terhadap isu di dalam film. Keterlibatan serta sudut pandang adalah dua hal yang saling berhubungan. Ketika pembuat film sudah terlibat berarti dia sudah mempunyai pengalaman empiris. Pengalaman empiris berfungsi untuk membangun sebuah sudut pandang terhadap sebuah isu. Ciri ekspresif dalam film dokumenter dengan bentuk performatif mengacu pada cara penyampaian informasi secara tidak biasa, layaknya sebuah dokumenter biasanya, meliputi cara penyampaian, teknik pengambilan gambar dengan penerapan aspek sinematografi sesuai, penerapan simbol, serta cara lainnya.

Film dokumenter performatif "REPOST" menyampaikan keterlibatan Vera dalam kehidupan Nia. Keterlibatan tersebut dibangun dengan menunjukkan interaksi antara Nia dan Vera serta menempatkan Vera sebagai orang yang menyaksikan dan merasakan kejadian demi kejadian bullying terhadap Nia. Prinsip dan kepercayaan Vera dalam memandang pengalaman empirisnya dan kakaknya digunakan untuk membangun sudut pandang ketidakberpihakannya terhadap isu bullying.

Cara penyampaian informasi dalam film dokumenter "REPOST" bermacammacam. Informasi disampaikan melalui simbol berupa lagu, penggunaan boneka sebagai pengganti tokoh Nia, penerapan teknik sinematografi seperti ukuran shot, editing, penerapan dutch angle dalam adegan rekonstruksi dan ilustrasi, serta penataan artistik. Setiap sequence dalam film dokumenter performatif memiliki motivasi tersendiri.

\section{Disain Program}

1. Bentuk Film : Dokumenter

2. Kategori Produksi: Non studio

3. Tema : Dampak negative dari bullying

4. Judul : "REPOST"

5. Durasi : 15 menit

6. Segementasi : 17-40 tahun, menengah atas dan bawah Lakilaki dan perempuan

7. Narasumber : Vera Isnaini Kurniawati

\section{Film Statement}

Bully dan cyberbullying adalah suatu tindakan negatif untuk semua orang yang dapat menyebabkan kerugian pada korban bakan menyebabkan gangguan psikologi. 
9. Sinopsis

Film dokumenter "REPOST" menceritakan isi hati seorang adik terhadap kasus bullying kakaknya. Nia sudah mengalami kasus bully dari kecil dan berlangsung sampai setelah wisuda karena kondisi fisiknya. Kasus tersebut membuat Nia menjadi sulit beradaptasi hingga depresi. Setelah sembuh dari depresi Nia kembali mendapat bully di Instagram. Adik merasa sangat khawatir hal tersebut dapat membuat tekanan batin Nia dan membuat depresinya kambuh lagi.

\section{Praproduksi}

Ide lebih dulu ditemukan sebelum melakukan proses pencarian data dan wawancara. Pada proses pencarian data, subjek diberikan beberapa pertanyaan yang relevan dengan ide. Setelah semua data terkumpul, proses pembuatan treatment dan naskah syuting dapat dimulai.

\section{a. Pencarian ide}

Ide film dokumenter "REPOST" di dapatkan dari pengalaman pribadi sutradara. Kejadian bully terhadap Nia sutradara di social media membuat sutradara ingin menyampaikan curahan hati melalui sebuah karya film dokumenter.

Ide film dapat dikembangkan dengan menentukan sebuah tema. Penentuan tema memberikan batasan dan fokus terhadap pencarian data, pengembangan ide, dan film statement.

b. Riset dan Wawancara
Proses riset dan wawancara dilakukan secara online dan intim antara sutradara dengan Nia. Seluruh data yang didapatkan akan dikonfirmasi secara langsung kepada Nia mengenai nilai faktual data. Nia memberikan persetujuan atas data yang boleh dan tidak boleh dimasukkan ke dalam materi film.

\section{c. Pembuatan Treatment}

Treatment dibuat setelah proses pembuatan sinopsis selesai dengan tujuan untuk memudahkan dalam proses pembuatan naskah shooting. Selain itu, treatment juga berfungsi untuk mempermudah tim produksi dalam melakukan proses pembuatan film.

d. Pembuatan naskah film

Naskah film terdiri dari kolom nomor scene, narasi, visual, dan audio. Nomor scene berisi angka dari scene disusun secara urut. Kolom narasi memuat jalan cerita dari film. Kolom visual berisi daftar gambar-gambar dalam scene dengan tambahan keterangan tambahan antara lain shot size atau ukuran gambar, camera angle atau sudut kamera, dan camera movement atau pergerakan kamera.

Film ini memiliki kekuatan pada bagian narasi sebagai pengarah jalan cerita. Sehingga unsur visual pada film secara mayoritas mengikuti narasi. Seluruh aspek seperti kejadian sebab dan 
akibat harus benar-benar diperhatikan. Narasi pada film ini bersifat fleksibel. Pada saat pascaprodusksi sering terjadi kekurangan materi sehingga narasi butuh direvisi hingga komposisi terasa pas.

e. Pembuatan naskah syuting

Naskah syuting yaitu sebuah naskah dengan fungsi sebagai pedoman syuting atau pengambilan gambar, termasuk suara. Shooting script terdiri dari tiga kolom yaitu kolom scene, shot, dan audio. Kolom scene memuat klasifikasi adegan berdasarkan cerita dan tempat, shot berisi keperluan gambar pada film, dan audio berisi keperluan suara untuk gambar.

\section{Produksi}

Tahap produksi dimulai dengan pengambilan gambar sesuai shot list. Beberapa proses produksi tidak disertai dengan pengambilan suara dan gambar di waktu bersamaan melainkan sendiri-sendiri. Hal tersebut sangat memungkinkan untuk dilakukan karena mayoritas adegan tidak menggunakan dialog atau monolog. Selain itu, alasan lain tidak disamakannya waktu saat perekaman suara dan gambar yaitu kondisi lokasi terlalu ramai. Namun, khusus untuk beberapa adegan dengan ekspresi menangis, teriak, serta pemandian dengan air bunga memerlukan suara asli dari adegan karena sangat sulit untuk melakukan sound replacement pada ketiga adegan tersebut.

a. Pengarahan pemeran

Pengarahan pemeran dilakukan sutradara ketika proses pengambilan gambar dan suara. Pada proses pengambilan gambar, pemeran diminta untuk melakukan adegan sesuai naskah dan kesepakatan saat reading. Pengarahan sendiri bertujuan untuk menjelaskan blocking atau penempatan.

b. Pengambilan gambar

Pengambilan gambar diarahkan secara langsung oleh director of photograph dengan aba-aba dari sutradara. Sebelum proses pengambilan gambar, dan pengadeganan, sutradara bersama director of photograph telah sepakat mengenain blocking atau penempatan pengadeganan.

\section{Pascaproduksi}

Pascaproduksi akan dilakukan setelah tahap produksi selesai. Pada tahap ini akan dilakukan proses editing mulai dari tahap offline hingga online editing. Tahap offline editing akan dilakukan dengan rough cut editing hingga mencapai fine cut. Sebelum memasuki online editing proses selanjutnya yaitu dubbing dan perekaman voice over. Online editing terdiri dari visual effect, grading, sound effect, ilm score, sound mixing, dan mastering.

a. Pengarsipan data produksi

Pengarsipan dara produksi dilakukan dengan mengklasifikasikan semua hasil produksi berdasarkan hari. setelah diklasifikasi perhari, lalu data tersebut diklasifikasinya bersasarkan adegan atau scene. 
b. Penyuntingan gambar (editing)

Penyusunan materi berpedoman pada editing script dan dilakukan oleh editor. Pada penciptaan karya ini sutradara merangkap menjadi editor sehingga lebih mudah dalam memilih gambar dan menyusun cerita. Sutradara sebagai 71 editor ini mempunyai menguntungkan karena dapat secara langsung memilih gambar yang akan dimasukkan. Offline editing merupakan proses tersusunnya semua materi dokumenter baik itu gambar dan wawancara sehingga alur cerita dapat terlihat dalam proses ini. Offline editing dilakukan dengan menerapkan treatment yang sudah ada hingga membentuk alur cerita.

Dalam proses offline juga dilakukan proses preview. Preview meliputi preview kepada dosen pembimbing dan kebeberapa pihak luar agar mendapat suatu masukan saran untuk hasil lebih baik. Offline editing ini juga tidak hanya sekedar menyusun gambar sesuai alur cerita, tetapi proses ini akan berakhir dan ketahap selanjutnya yaitu online editing. Jika sudah picture lock, yaitu tidak adanya lagi revisi alur cerita dan gambar yang telah disetujui oleh dosen dan picture lock ini didapatkan dengan penyuntingan gambar berkali-kali hingga hasil video tidak terasa begitu lama serta hasil visual dan isi kontennya pun bisa disampaikan dengan menarik.

c. Dubbing dan perekaman voice over

Pengarahan pemeran tidak hanya dilakukan pada saat syuting di lapangan, namun dilakukan pada saat proses dubbing dan perekaman voice over. Fungsi pengarahan tersebut adalah untuk mendapatkan tingkat emosi yang diinginkan sesuai dengan motivasi penggunaan dalam film. Hasil dubbing akan diletakkan untuk audio replacement pada pemeran non manusia seperti boneka. Proses perekaman voice over adalah proses perekaman narasi film.

d. Color grading, scoring, mixing, dan mastering

Ketiga proses tersebut merupakan proses online editing. Online editing adalah proses akhir mensingkronkan semua susunan gambar, seperti menyamakan warna, mixing suara serta teks atau subtitle keterangan di beberapa gambar. Proses online editing ini merupakan proses penting paling akhir agar siap untuk tahap screening.

\section{Pembahasan Karya}

Sebuah film dokumenter dengan bentuk performatif memiliki ciri-ciri bersifat subjektif, ekspresif, bersifat ingatan, dan pengalaman. Seluruh isi dari 
film dokumenter diangkat dari ingatan dan pengalaman Vera dan Nia. Subjektivitas dalam film dokumenter performatif dapat menjelaskan secara langsung keterlibatan pembuat film di dalam film dan posisi keberpihakan pembuat film terhadap isu di dalam film. Keterlibatan serta sudut pandang adalah dua hal yang saling berhubungan. Ketika pembuat film sudah terlibat berarti dia sudah mempunyai pengalaman empiris. Pengalaman empiris berfungsi untuk membangun sebuah sudut pandang terhadap sebuah isu. Ciri ekspresif dalam film dokumenter dengan bentuk performatif mengacu pada cara penyampaian informasi secara tidak biasa, layaknya sebuah dokumenter biasanya, meliputi cara penyampaian, teknik pengambilan gambar dengan penerapan aspek sinematografi sesuai, penerapan simbol, serta cara lainnya.

Film dokumenter performatif "REPOST" menyampaikan keterlibatan Vera dalam kehidupan Nia. Keterlibatan tersebut dibangun dengan menunjukkan interaksi antara Nia dan Vera serta menempatkan Vera sebagai orang yang menyaksikan dan merasakan kejadian demi kejadian bullying terhadap Nia. Prinsip dan kepercayaan Vera dalam memandang pengalaman empirisnya dan kakaknya digunakan untuk membangun sudut pandang ketidakberpihakannya terhadap isu bullying.

Cara penyampaian informasi dalam film dokumenter "REPOST" bermacam- macam. Informasi disampaikan melalui lagu, penggunaan boneka sebagai pengganti tokoh Nia, penerapan teknik sinematografi seperti ukuran shot, editing, penerapan dutch angle dalam adegan rekonstruksi dan ilustrasi, serta penataan artistik. Setiap sequence dalam film dokumenter performatif memiliki motivasi tersendiri. Rekonstruksi adalah merangkai kembali fakta untuk merepresentasikan dalam bentuk drama. Menurut Gerzon, dalam tipe rekonstruksi, pecahan-pecahan atau bagian-bagian peristiwa masa lampau maupun masa kini disusun berdasarkan fakta (Gerzon, 2008:46).

\section{Sequence 1}

\section{a. Aspek Subjektif}

Aspek subjektif pada sequence ini diaplikasi dengan pemilihan cerita dan sudut pandang cerita. Unsur cerita, video, dan foto-foto masa kecil dipilih untuk memberikan gambaran tentang masa kecil Vera dan Nia. Pengarahan cerita menuju tokoh Nia sebagai kakak dari Vera sudah dimulai dari sequence 1. Bagian awal sequence menceritakan tentang keluarga Nia secara singkat, bagian tengah mengerucut ke interaksi antara Vera dan Nia, dan pada bagian akhir semakin mengerucut kearah keinginan Nia untuk sekolah serta hadiah meja belajar baru dari Bapak untuk Nia. b. Aspek Ingatan dan Pengalaman 
Sequence 1 berisi pengalaman dan ingatan Vera mengenai masa kecilnya dengan Nia di rumah. Mereka adalah dua orang saudara. Mereka berdua sama-sama memiliki kesamaan senang memelihara binatang. Hal ini mereka dapatkan dari Bapak yang juga senang memelihara binatang. Nia sangat sayang dengan binatangnya. Dia bisa menangis histeris jika tahu binatangnya tidak ada di rumah. Binatang bagi Nia bisa sangat berarti layaknya seorang sahabat. Bapak mengajarkan anak-anaknya untuk mencintai sesama makhluk melalui binatang peliharaan.

\section{c. Aspek Ekspresif}

Keterangan grafis pada bagian dokumentasi foto digunakan untuk melengkapi informasi yang tidak bisa dijelaskan melalui narasi. Grafis tersebut seolah-olah berbentuk tag atau tanda pengenal di Instagram. Fungsi tag pada foto-foto adalah untuk memberikan keterangan identitas objek atau orang pada foto. Tulisan pada tag merupakan nama panggilan masa kecil Nia, "Mbak Nia", dan Vera, "Dek Vera". Foto tidak akan dibiarkan diam melainkan akan diberi tambahan pergerakam zoom in. Penambahan pergerakan dan ukuran foto digunakan untuk memberikan pergerakan gambar menjadi besar.

Video hewan peliharan direkam secara spontan mengikuti gerakan binatang.
Kamera dipegang secara handheld tanpa bantuan alat untuk menstabilkan gambar. Posisi gambar pada saat musang diberi makan dibiarkan tegak vertikal dengan aspek rasio 9:16. Bentuk frame vertical dan penggunaan tambahan grafis tag pada bagian sebelumnya dimaksudkan untuk menunjukkan kebiasaan orang-orang ketika bermedia sosial. Aktivitas merekam dan memotret objek mengikuti frame pada handphone, yaitu vertikal, untuk kebutuhan unggahan Instagram story atau jenis story lainnya.

\section{Sequence 2}

a. Aspek Subjektif

Sequence dua berisi ketidakberpihakan Vera terhadap perilaku teman-teman Nia terhadap Nia. Ketidakberpihakan tersebut disampaikan secara verbal melalui narasi dan hanya disampaikan melalui sudut panda Vera. b. Aspek Ingatan dan Pengalaman

Vera dan Nia bersekolah di tempat yang sama. Mereka hanya berjarak tiga tahun. Nia kelas 4 sekolah dasar dan Vera kelas 1 sekolah dasar. Vera tidak suka dengan teman-teman Nia. Temantemannya sering menuduh dan menyalahkan Nia tanpa bukti. Nia sering diintimidasi oleh teman-temannya dikelas dengan cara diberi sorakan. 
c. Aspek Ekspresif

Sequence dimulai dengan menunjukkan situasi sebuah sekolah. Anakanak berbaju kemeja putih dan bawahan (rok/celana) merah mendeskripsikan keterangan sekolah yaitu sekolah dasar. Keterangan mengenai sekolah dasar ditambah dengan suara-suara anak-anak ketika bermain di luar kelas. Ketidaksukaan Vera terhadap teman Nia dijelaskan melalui narasi, sementara alasannya disampaikan melalui sebuah adegan rekonstruksi.

Kejadian mengenai dituduhnya Nia oleh teman-teman direkonstruksi secara ekspresif melalui sebuah shot boneka beruang berbaju seperti anak sekolah dasar terdiam di antara suara tuduhan dan sorakan teman-teman Nia. Shot boneka beruang diberi efek zoom in pada saat intimidasi dimulai sebagai bentuk tekanan dan ketidaknyamanan. Selain membicarakan tuduhan, narasi juga membicarakan mengenai kesendirian Nia dalam menghadapi intimidasi teman-temannya.

\section{Sequence 3}

\section{a. Aspek Subjektif}

Sudut pandang cerita dari sequence ini mengambil ingatan Vera mengenai masa-masa ketika dia dan kakaknya menghadapi permasalahan ketika kecil. Pemilihan sudut pandang Vera dalam menceritakan permasalahannya dengan Nia memunculkan sebuah informasi mengenai ketidakjelasan alasan Nia menjauh dari Vera dan tidak mau bermain bersama.

b. Aspek Ingatan dan Pengalaman Seperti masa kecil anak-anak lainnya, Vera dan Nia ketika kecil tidak selalu bermain bersama. Ada masanya ketika mereka kadang mengalami konflik. Konflik tersebut kadang membuat Nia tidak mau bermain bersama Vera.

c. Aspek Ekspresif

Ciri ekspresif film "REPOST" terdapat pada bagian ini. Cerita disampaikan melalui lagu. Penyanyi lagu "Do You Wanna Build A Snowman" dalam film "REPOST" adalah Vera. Dia bisa bermain gitar sambil bernyanyi. Beberapa permainannya didokumentasikan dirinya sendiri. Dokumentasi permainan gitar dan bernyanyi digunakan untuk menyampaikan sebuah pesan mengenai ingatannya tentang masa lalu. Ingatan tersebut adalah sebuah kondisi di mana Nia dan Vera tidak selalu akur. Tanpa menyebutkan alasan yang jelas pada film, Vera dan Nia pernah berkelahi dan tidak mau main bersama ketika kecil.

Cerita direpresentasi melalui lagu berjudul "Do You Wanna Build A Snowman" pada film "Frozen". Berikut ini terjemahan lagu "Do You Wanna Build A Snowman" dalam Bahasa Indonesia. 


\section{Sequence 4}

a. Aspek Subjektif

Aspek subjektif pada sequence ini ditunjukkan dengan menampilkan persepi Vera terhadap teman-teman Nia ketika SMA. Vera sering kali datang ke sekolah Nia untuk pulang bersama. Dia memperhatikan bagaimana teman-teman Nia berinteraksi dengan Nia. Tidak hanya itu, Vera sering melihat bagaimana interaksi Nia dan temantemannya di media sosial Facebook. Vera merasakan banyak teman-teman kakaknya yang membuat julukan tertentu untuk mengejek Nia.

b. Aspek Ingatan dan Pengalaman

Nia jarang mempunyai teman yang banyak. Walaupun dia mempunyai teman dekat, pernah teman dekatnya mempermalukan Nia di depan temantemannya. Nia sering dibully secara verbal oleh temannya. Teman Nia mengejek Nia secara berulang-ulang dengan menyuruh Nia dengan kata-kata "hembuskan". Maksud dari hembuskan tidak dijelaskan secara jelas, melainkan secara tersirat. Menghembuskan adalah kegiatan untuk mengeluarkan nafas dari hidung. Ejekan untuk menghembuskan berarti ada sebuah penghinaan terhadap kondisi hidung Nia.

c. Aspek Ekspresif

Grafis tampilan Facebook dijadikan sebuah gambaran mengenai kehidupan sosial Nia. Bukan berarti angka dari jumlah pertemanan Nia saat itu sama dengan film.
Penggunaan grafis pertemanan di Facebook dengan keterangan Nia sebagai pemilik akun ditujukan untuk menunjukkan gambaran bertapa sedikitnya teman yang dimiliki Nia.

Sequence ini kembali dibantu penceritaannya dengan bantuan narasi dan lagu ciptaan Vera. Lagu tersebut menyampaikan secara halus alasan mengapa Nia tidak memiliki teman banyak yaitu fisik. Nia sering dibully karena fisiknya tidak memasuki parameter cantik menurut teman-temannya. Salah satu temannya menulis komentar di Facebook dengan maksud untuk mengejek. Ejekan tersebut dibuat secara tersirat, yaitu dengan kata "hembuskan". Dalam Bahasa Inggris "hembuskan" memiliki arti "blow away" sehingga lagu dalam film berjudul "Blow Away". Lagu tersebut menggunakan campuran Bahasa Indonesia dengan Bahasa Melayu.

\section{Sequence 5}

a. Aspek Subjektif

Nia pernah bercerita tentang perlakuan teman-temanya ketika study tour di luar kota. Pengalaman tersebut tidak hanya membuat Nia sedih, melainkan membuat Vera dan keluarga menjadi sangat marah dan kecewa dengan perlakuan teman kelas terhadap Nia. Sequence ini menyampaikan jalan cerita kejadian secara subjektif hanya dari sudut pandang Vera. Sudut pandang ini memposisikan tokoh Nia 
sebagai korban. Walaupun dalam proses penceritaanya menggunakan sudut pandang satu pihak, namun isi dari cerita merupakan fakta.

b. Aspek Ingatan dan Pengalaman

Nia pernah dijahili teman dekatnya dan membuat Nia menjadi sakit hati. Nia menangis di bis ketika perjalanan pulang hingga ke rumah. Teman dekatnya memotret ketika dia mengenakan baju dan menyebarkan foto tersebut ke teman kelasnya. Kasus ini terjadi ketika Nia dan teman-temannya pergi study tour ke Sambas, salah satu kabupaten di Kalimantan Barat. Kabupaten Sambar berjarah lima sampai enam jam dari rumah Nia.

c. Aspek Ekspresif

Pemilihan Gmaps untuk menyampaikan informasi lokasi kejadian di dalam cerita diadaptasi dari kebiasaan orang dalam bertukar atau berbagi lokasi pada saat ini. Selain itu, grafis dengan informasi peta dari Pontianak ke Sambas melalui media Gmaps juga bertujuan untuk memberikan informasi lokasi dan waktu tempuh kejadian. Video reka adegan muncul seperti notifikasi berita dengan materi video. Notifikasi tersebut disentuh pengguna handphone sehingga muncul video utuh. Munculnya notifikasi dijadikan transisi perubahan dari peta ke adegan rekonstruksi ketika Nia di potret oleh temannya di kamar hotel.

Setelah gambar di pojok kanan bawah muncul maka seorang pengguna handphone akan seolah-olah memencet video tersebut dan rekonstruksi adegan dimulai. Rekonstruksi diciptakan dengan menggunakan pemeran pengganti Nia dan tampak tangan sedang memotret pemeran Nia saat baru keluar kamar mandi dan hendak mengenakan baju. Set ruang dibuat seolah-olah hotel dengan dukungan lampu tidur, alas Kasur berwarna putih dan suasana ruangan berwarna hangat. Baju Nia diletakkan di atas kasur sesuai pengalaman ketika menginap di hotel. Lemari jarang sekali digunakan untuk meletakkan baju jika hanya menginap satu atau dua hari sehingga baju bisa diletakkan di mana saja misalnya di kasur. Gambar dibuat menjadi slow motion dengan tujuan memberikan sinyal ke penonton untuk memperhatikan lebih jelas pergerakan objek pada gambar karena ada sebuah kasus di dalam gambar tersebut yaitu pemotretan secara diam-diam terhadap Nia.

\section{Sequence 6}

a. Aspek Subjektif

Tidak semua orang pernah mengalami salah satu dari anggota keluarga mereka mengalami depresi. Sequence ini memuat pengalaman mengenai bagaimana suasana dan perasaan keluarga Nia secara personal mengenai Nia ketika mengalami depresi.

b. Aspek Ingatan dan Pengalaman

Sequence 6 menggambarkan ketidakstabilan tokoh Nia secara mental dan psikis. Keluarga Nia bingung terhadap perubahan sikap Nia sangat aneh. 
Terkadang Nia menjadi sangat takut terhadap situasi, melihat dengan tatapan kosong, dan tidak fokus dengan situasi dan kondisi di sekitarnya.

c. Aspek Ekspresif

Sequence ini menceritakan kondisi keluarga Vera dan Nia ketika mendapat masalah, yaitu Nia mengalami depresi. Permasalahan di dalam kondisi keluarga Nia diinterprestasikan sebagai sebuah ketidakstabilan kondisi karakter, atau dengan istilah lain kondisi karakter dalam cerita sedang tidak baik-baik saja. Ketidakstabilan situasi divisualisasikan dengan simbol berupa gambar lampu jalanan ketika hujan rintikrintik di malam hari. Banyak film dengan genre romance atau kisah cinta menggabungkan adegan menangis dengan hujan deras, sehingga hujan sangat identik dengan kesedihan. Kesedihan pada bagian ini ditunjukkan dengan kondisi hujan di jalanan. Gambar tersebut diambil dengan penerapan dutch angle untuk menyampaikan sebuah ketidakseimbangan situasi atau keadaan tidak baik (muncul sebuah masalah).

Nia ternyata mengalami depresi berat. Bagian ini memuat rekonstruksi yang tidak dilakukan secara utuh pada sebuah adegan melainkan secara ringkas mengenai perilakuperilaku aneh Nia ketika depresi. Antara lain pandangan matanya yang kosong, tidak fokus terhadap sekelilingnya. Tatapan kosong dan ketidakfokusan Nia direpresentasikan dengan adegan seorang tokoh wanita diam tanpa ada pergerakan.

Perban adalah salah satu barang medis yang digunakan untuk membalut luka, sehingga perban sangat berhubungan dengan sakit pada manusia. Sementara kepala adalah pusat kontrol dari tubuh manusia. Maksud dari lilitan pada kepala pemeran Nia bukan untuk menjelaskan adanya kesakitan fisik yang dialami Nia. Fungsi penggunaan perban pada tokoh Nia yaitu untuk merepresentasikan ketidaknormalan (sakit) terjadi pada Nia dalam mengontol badan dan pikirannya. Sementara lingkar hitam disekeliling matanya mendeskripsikan pola hidup atau tidur yang tidak sehat. Secara sederhana, make up tersebut ingin menyampaikan pesan kesehatan jiwa Nia yang tidak baik.

\section{Sequence 7}

a. Aspek Subjektif

Sequence ini merupakan bentuk dari interpretasi terhadap sebuah rasa patah hati seorang wanita. Cinta adalah sebuah rasa kasih sayang dan ingin memiliki. Ketika orang yang dicintai lebih memilih orang lain untuk dicintai, maka menjauh dan diam adalah cara untuk mengobatinya. Ungkapan tersebut didapatkan dari pandangan Vera terhadap sikap Nia ketika dia suka kepada orang lain namun orang tersebut sudah memiliki pasangan. 
b. Aspek Ingatan dan Memori

Sequence 7 merupakan sebuah ilustrasi kesedihan Nia ketika cintanya bertepuk sebelah tangan. Nia pernah jatuh cinta kepada seorang laki-laki. Namun, laki-laki tersebut sudah bersama wanita lain. Nia akhirnya patah hati dengan kondisi laki-laki tersebut mengetahui bahwa Nia memiliki rasa cinta kepadanya.

c. Aspek Ekspresif

Gambar pada sequence ini menggunakan rasio aspek 1:1 dengan penerapan gaya monochrome/grayscale pada gambar. Kedua aspek sinematografi tersebut digunakan untuk menyampai sebuah ketidaknyamanan (tertekan) pada masa lalu tokoh.

Sequence singkat ini akan berhubungan dengan sequence selanjunya. Adapun simbol tersebut disampaikan melalui properti bunga mawar di tangan seorang wanita. Ketika wanita yang memegang bunga melihat ke arah depan, tampak seorang pasangan sedang bergandengan tangan. Lalu wanita berlari ke arah belakang seakan-akan menghindari pasangan tersebut. Wanita lalu bersedih di tepi pantai. Penjelasan bahwa tokoh tersebut adalah Nia disampaikan melalui boneka di depannya.

\section{Sequence 8}

\section{a. Aspek Subjektif}

Curahan hati di dalam ruang obrolan WhatsApp merupakan pengalaman personal Vera di tengah menemai Nia ketika depresi. Cerita disampaikan secara langsung melalui sudut pandang Vera dengan tujuan untuk menciptakan sebuah kedekatan antara Vera dengan pembaca curahan hati, sama seperti ketika kita menerima curhatan orang lain secara langsung, akan terjalin kedekatan antara orang yang sedang curhat dengan pendengar atau pembaca curahan hati.

b. Aspek Ingatan dan Pengalaman

Sequence 8 memuat curahan hati dan sedikit cerita dari Vera ketika Nia mengalami depresi. Nia terkadang mengalami penurunan kepercayaan diri ketika dia mengalami depresi. Penurunan kepercayaan diri ditunjukkan dengan pertanyaan dirinya mengenai kondisi wajahnya. Nia juga sering menyebutkan keinginannya untuk bertemu dengan seorang laki-laki idamannya. Nia sering menyebut namanya secara terus menerus. Pertanyan itu secara langsung ditanyakan Nia kepada Vera secara langsung dan membuat Vera sedih.

c. Aspek Ekspresif

Curahan hati Vera terhadap kondisi Nia ditampilkan melalui ruang obrolan WhatsApp. Penyampaian pesan mengenai curahan hati melalui tampilan Whatsapp diadaptasi dari kebiasaan orang-orang pada era ini untuk berbicara melalui WhatsApp. Obrolan di WhatsApp bisa terasa lebih emosional dibanding dengan berbicara secara langsung dengan tambahan gambar emoticon.

Ilustrasi musik pada sequence ini digunakan untuk mengiringi suasana di 
dalam ruang obrolan WhatsApp. Ilustrasi musik (film score) adalah musik latar yang mengiringi aksi selama cerita berjalan (Pratista, 2018:202).

\section{Sequence 9}

a. Aspek Subjektif

Sequence 9 memuat pandangan terkait tidak adanya kebaikan dalam perilaku bullying dan body shaming, melainkan hanya kejelekan. Hal tersebut didukung dengan datadata dari berita mengenai bullying dan juga body shaming. Data terdiri dari berita-berita mengenai mulai maraknya kasus bullying di sekolah, media sosial, mulai dari kalangan pelajar, dan kalangan public figure. Undangundang mengenai body shaming juga ditampilkan pada berita untuk menunjukkan perhatian Indonesia terhadap kasus bullying dan body shaming.

b. Aspek Ingatan dan Pengalaman

Nia sering tidak fokus ketika depresi. Dia terkadang hanya diam dan tidak melakukan apa-apa. Nia mengalami ketidakstabilan emosi ketika dia depresi. Nia bisa berubah menjadi sangat menyeramkan ketika depresi. Dia pernah memecahkan gelas di dapur tanpa alasan. Kejadian pecahnya gelas di dapus oleh Nia direkonstruksi pada sequence ini.

c. Aspek Ekspresif

Tokoh pengganti Nia terlihat duduk diam dimeja makan. Terdapat roti, selai, dan gelas minum di hadapan Nia. Ketidakfokusan Nia terhadap apapun dilingkungannya diperlihatkan dengan diam di meja makan tanpa melakukan apapun selain menangis, bahkan roti dihadapannya masih utuh. Tidak ada ingatan atau pengalaman khusus mengenai roti. Roti hanya menjadi simbol untuk menunjukkan adanya makanan di hadapan Nia, begitu juga dengan gelas dan selai. Adegan ini merupakan sebuah ilustrasi untuk menyampaikan kondisi Nia ketika depresi, yaitu hanya diam, terkadang menangis sendiri, dan tidak memerhatikan lingkungannya.

Shot wanita di atas meja makan memiliki ukuran shot luas. Nia duduk di tengah ruangan yang luas dan sendiri. Nia Penataan lampu pada adegan di meja makan difokuskan kepada tokoh wanita. Bagian belakang wanita hanya mendapatkan cahaya terusan dari lampu utama, sehingga bagian tersebut terlihat gelap. Kegelapan pada bagian belakang wanita dimaknai sebagai sebuah kesuraman di kehidupan Nia saat itu.

Untuk mengangkat tensi pada sequence ini gambar dipindahkan dengan tempo perpindahan cepat disertai dengan suara-suara berita di televisi yang bersautsautan dan bertimpa namun tetap jelas didengar.

\section{Sequence 10}

a. Aspek Subjektif

Pemilihan informasi pada sequence 10 dilakukan secara subjektif hanya sebatas kasus cyberbullying semata tanpa 
diinformasikan bagaimana kasus itu bisa terjadi. Pemilihan tersebut dilakukan sesuai dengan pertimbangan dramatik cerita serta untuk memperlihatkan betapa kasihannya Nia, tidak berapa lama sembuh, dia kembali mendapatkan bullying bahkan di media sosial (cyberbullying).

b. Aspek Ingatan dan Pengalaman

Setelah Nia sembuh dari depresi, Nia kembali membuka diri di media sosial. Nia mempunyai akun Instagram, Youtube, dan media sosial lainnya. Nia merupakan wanita berbakat. Tulisan Nia pernah dibukukan. Nia seakan tidak pernah lepas dari kasus bullying. Vera menemukan unggahan salah satu akun besar di Pontianak berisi Nia sedang berada pada sebuah acara dan melambaikan tangan pada kamera. Video tersebut telah dilihat dan dikomentari banyak pengguna Instagram lain. Isi dari komentar pada unggahan tersebut lebih banyak menyinggung kondisi hidung Nia, body shaming.

c. Aspek Ekspresif

Keterbukaan Nia terhadap dunia luar ditunjukkan dengan memperlihatkan Nia sedang duduk di sebuah tempat terbuka sambil mengetik pada handphone. Foto sebuah buku berjudul "Aktivis Rumahan" dengan nama "Kurniawati" di bawah judul menunjukkan bahwa buku tersebut ditulis secara langsung oleh Nia. Video boomerang (salah satu jenis efek gambar pada media sosial Instagram) bersama Vera menunjukkan keaktifan Nia dalam mengaskses Instagram. Video selanjutnya adalah hasil unggahan pada saluran Youtube pada akun milik Nia. Nia sudah bisa berbicara di depan kamera bahkan berjoget mengikuti alunan musik.

Kasus cyberbullying ditunjukkan dengan video hasil rekaman dari layar handphone. Video dengan wajah $\mathrm{Nia}$ diunggah ulang oleh akun dengan nama Pontianak Media. Selanjutnya ditampilkan komentar-komentar dari penggunapengguna Instagram lain mengenai video unggahan ulang tersebut.

\section{Kesimpulan}

Film dokumenter "REPOST" adalah sebuah karya seni dokumenter bertema dampak negatif dari bullying. Film ini berhasil menceritakan kisah hidup korban bullying secara personal dengan membawa intensitas emosional ditinjau dari pendapat audience pada pemutaran pertama.

Performatif sebagai salah satu bentuk dari dokumenter sangat cocok digunakan dalam film "REPOST". Performatif menawarkan sudut pandang sangat subjektif, ekspresif, serta bersifat memory anda experience atau ingatan dan pengalaman. Film dokumenter "REPOST" muncul dari perasaan sedih dan kesal seorang adik terhadap kasus cyberbullying yang menimpa kakaknya. Alasan dari kekesalan adik tersampaikan secara sangat subjektif di mana dia menceritakan bagaimana kelamnya masa lalu kakak sebagai korban bully hingga kakak 
menderita depresi berat. Pada akhirnya setelah kakaknya sembuh, kakak si adik harus kembali menjadi korban bully. Penggunaan bentuk performatif membantu sutradara dapat secara bebas dalam mengeluarkan statement dan memilih posisi kontra terhadap kejadian bullying terhadap Nia, kakaknya.

Film ini menyampaikan informasi secara ekspresif. Cara penyampaian tersebut antara lain menggunakan simbol, lagu, elemen-elem shot pada adegan rekonstruksi, dan penggunaan ilustrasi musik untuk mengiringi aksi pada beberapa bagian film.

\section{Daftar Pustaka}

[1] Ayawaila, Gerzon R, ed.1. Dokumenter Dari Ide Sampai Produksi. Jakarta: FFTV -IKJ Press, 2008

[2] Nichols, Bill. Introduction to Documentary. Bloomington: Indiana University Press, 2010.

[3] Pratista, Himawan. Memahami Film. DIY: Montase Press, 2018. 